\title{
Environmental Green Accounting and Auditing Practice
}

\author{
Nur eny Lolo* \\ Makassar State University of Indonesia \\ Muh. Rum \\ Postgraduate Program of Muhammadiyah Universiy Makassar of Indonesia
}

\begin{abstract}
Environmental accounting reflects a business to capture in financial portrait system connecting with the environment and must impact to an ecosystem where their operating system involves in. The main criticism to accounting is environmental devastation, specifically deforestation and waste. The objectives of this study are to describe the rationale of why a business entity willing to undertake an environmental audit, what is the main benefit and costs to carry out an environmental audit, how the role of an environmental audit within an environmental management system and describe environmental costs on environmental accounting. Commonly multinational companies can contribute towards, sustainable environment by innovating and improving their products and processes in order to use raw materials more efficiently in reducing waste generated from production proces, improving waste disposal methods and improving work conditions (Joseph et.al, 2016). This study employed descriptive studies to describe various aspects of environmental aspect and accounting treatment to the whole criticism, which regarding as payable account. This study explained as a state of affairs as they are at present with the researcher having no control over the variable. The result in, environmental cost accounting represents a set of principles and approaches providing essential information for the specific activities in environmental management. Environmental accounting discloses the environmental costs - it is a system of planning and managing the environmental performance which should reflect the managerial style and commitment of the economic entity management to the environment. It has the relevance of integrating environmental issues in the financial and decisional economic entity. Environmental accounting can produce a lot of benefits for an organization, including cost savings and increased management effectiveness and both large and small organizations, moreover can benefit from undertaking an environmental audit. Environmental costs have been recorded according to the types of expenses according to their functions should be reflected in the costs and expenses of the current accounting period.
\end{abstract} Keywords: Environmental Accounting and Auditing, Cost and Benefit, Sustainable Environment DOI: $10.7176 / \mathrm{RJFA} / 10-8-07$

Publication date: April $30^{\text {th }} 2019$

\section{INTRODUCTION1}

Accounting is an entire portrait which depicts the whole factors involved in a business entity. Accounting in one environmental business can capture in portrait system each entity business which connected with the environment and has an impact on the ecosystem where their operating system involves in. The worst claim to accounting is environmental devastation are deforesting and wasting. Forest and land damaged caused by various human activities such as cultivation, encroachment, illegal logging, and forest fire the last few years have caused the area of forest to shrink of deforested, which to date is estimated at 2.83 million ha per year of deforestation area forest (MoEF, 2016). Almost 70 percent of environmental damage caused by mining companies (Bangka Pos, 28 September 2012). This industry often outsmarts rules that conflict with its interests. In Indonesia, there are already four mining sector companies allegedly polluting a number of rivers in the company's operating area, there is sitting up to the damage of the river (Bisnis Indonesia Mobile, 28 May 2012).

MoEF (2016) refer to The Conference of Party (COP) under the United Nations Framework Convention on Climate Change (UNFCCC) invites developing countries aiming to undertake Reducing Emissions from Deforestation and forest Degradation (REDD+) activities to provide a number of strategic documents. Indonesia accepts the invitation to voluntarily submit proposed national forest reference emission level (FREL) for deforestation and forest degradation in the context of results-based payments for activities relating to REDD+. The FREL in this submission revises the previous FRELs, which had been developed under three initiatives, namely Second National Communication (SNC), REDD+ Agency (RA) and Ministry of Forestry (MoFor). This submission fulfills the COP requirements by following the guidelines for technical assessment and adopting principals on transparency, accuracy, completeness, and consistency. Bebbington, Gray, Thomson, and Wolters (1994) confirmed that accountants have low levels of involvement in their company's environmental activities and appear to experience a conflict between their awareness of environmental issues and an inability to translate this into action within their corporate life. Jaggi and Zhao (1996) the perceptions of management accountants on environmental reporting practices, although managers were concerned about the protection of the environment, that concern was not reflected in voluntary environmental disclosures. 
Environmental accounting is one tool to help companies to understand the possibility of environmental obligations that will arise in the future. There are many companies involve in contributing chemical and waste pollutant such as the four companies are Adaro Indonesia Co.Ltd contaminates Balangan River, South Kalimantan with overflow case of sedimentation reservoir pond. Secondly, and Arutmin Indonesia Co.Ltd contaminates the Salajuan River, South Kalimantan with the case making the river water black. Third, Freeport Indonesia Co.Ltd contaminates the Akjwa River, Papua with tailings. Fourth, PT Kideco Jaya Agung Co.Ltd contaminates the Biu River and the Samurangau River, East Kalimantan, has caused siltation and muddy. This negative reporting can be detrimental to the company because the image of the company gets worse. In addition to, a lack of environmental care corporate can lead to the emergence of environmental obligations in the future. (Bisnis Indonesia Mobile, 28 May 2012)..

In the era of the movement of the company towards a green company, the industry not only required to the extent of sewage treatment, but also the demands of society-consumers for a production process of goods ranging from making raw materials to the disposal of a product when consumed or used, but does not damage the environment. The concept of green accounting has developed since the 1970s in Europe, followed by the beginnings of studies related to the issue of green accounting in the 1980s (Bebbington, 1994; Gray et al., 1995). In the mid-1990s The International Accounting Standards Committee/IASC developed the concept of international accounting principles, including the development of environmental accounting and auditing human rights. Green accounting is important because the company needs to submit information on social activities and environmental protection to the stakeholders of the company.

Previous studies on environmental accounting have focused on companies or the accounting profession. Todea, $\mathrm{N}$ et.al (2011), explore about accounting policies on environmental costs and their calculation method in the entity, the aforementioned aspects show that environmental accounting is an instrument used by the entities to prevent and remove the effects of pollution, to control costs and to improve environmental performance. Choudhary (2015), explore about the environmental audit: a need for sustainable development of mining industry, revealed that environmental audit increase management and employee awareness of environmental issues, more efficient resources use and financial savings and promotes 'Good Practices'. Providing better private and public image and security to top management. Magara et.al (2015), explore about the effect of environmental accounting on company financial performance, findings revealed that constructs of Environmental Accounting application (environmental information, environmental evaluation, compliance of environmental laws and tracking of environmental cost savings) are significantly positively related to the perceived financial performance of the corporate organizations.

The objectives of the study are describing the reason why an entity business wish to undertake an environmental audit, what is the main benefit and costs from carrying out an environmental audit, how the role of an environmental audit within an environmental management system, and describing the environmental costs on environmental accounting. The accounting system in which there are accounts related to environmental costs is referred to as green accounting or environmental accounting. Green accounting or environmental accounting is accounting in which there are identification, measurement, and allocation of environmental costs, where the environmental costs are integrated into business decision-making, and subsequently communicated to stakeholders.

Stakeholders obviously require companies to manufacture goods efficiently and at competitive prices without degrading the environment. Tanc \& Gokoglan (2015), presented about the impact of environmental accounting on strategic management accounting, revealed that the environmental accounting has gained importance in order to deal with global competition which forms the basis of strategic management accounting; because environmental costs can be minimized by applying strategic management accounting techniques. Seetharaman et.al (2007), presented about environmental accounting as a tool for environmental management system, revealed that An organization can contribute towards sustainable environment by innovating and improving their products and processes in order to use raw materials more efficiently, reduce the waste generated from their processes, improve the waste disposal methods and improve the work conditions. Joseph et.al (2016) also revealed that multinational companies can contribute towards, sustainable environment by innovating and improving their products and processes in order to use raw materials more efficiently reduce the waste generated from their processes, improve the waste disposal methods and improve the work conditions.

The problem statements that the writer formulates are undertaking audit by an organization, cost, and benefit of an environmental audit, environmental audit role, and accounting treatment for environmental costs. Management policies for environmental costs lead to a reduction in long-term costs and an increase in the benefit claimed. Chivu (2015), explore about environmental costs from the perspective of environmental accounting, revealed that environmental accounts should provide data showing both the contribution of natural resources for economic welfare and costs for contamination or exhausted. Environmental costs can be reduced or avoided through pollution prevention practices such as redesigning products, input materials substitution, practices and improve the operational level of maintenance. Ileana \& Andrea (2014) also revealed that environmental accounting, by the environmental cost, is a fundamental instrument in providing pertinent information for making correct 
decisions in the economic entities, and in the publication and dissemination of this information in the annual reports and situations of economic entities. The managers of the capital, as well as other parties concerned, to which the economic entity has a certain social responsibility, use accounting to obtain information on the consequences of the economic growth on opportunities and environmental costs.

\section{THEORETICAL BACKGROUND}

As for traditional accounting management for each product or service work is necessary to calculate costs of production per unit of measure, and for environmental management, accounting should be made to calculate average costs per average sequence performed on each subdomain environment. Todea, et.al (2010), presented about environmental accounting as a tool used by the entity for determining environmental costs, revealed that the ability of environmental management accounting to reflect environmental costs that the entity is to prevent, treat or repair the damage it has caused to the environment. Emeakponuzo \& Udih (2015), presented about environmental accounting practices, revealed that the input of environmental staff is important in cost categorization and tracking of cost in developing an environmental management system.

It was discovered that legal staff labor time and natural resources damages are the least internal costs included in environmental project financial evaluation. It has been established in this study that the establishment of an Environmental Management System (EMS) is essential for corporate firms in Nigeria. This is an important task to ensure that all relevant, significant costs are considered when making business decisions. Senol \& Ozcelik (2012) also revealed that the most important element of environmental accounting is environmental costs. Focus on the environmental costs, environmental costs will be controlled facility. According to the types of environmental costs should be included in the accounting information system. Environmental costs (Environmental activity type costs, costs that represent traditional accounting, Environmental domain type costs, costs which reflect data visibility in the accounting records) have been recorded according to the types of expenses according to their functions should be reflected in costs and expenses of the period.

\section{RESEARCH METHODOLOGY}

Descriptive studies are used to describe various aspects of the phenomenon. In its popular format, descriptive research is used to describe characteristics and/or behavior of the sample population. This study applied descriptive research can be explained as a state of affairs as they are at present with the researcher having no control over a variable. Descriptive studies may be characterized as simply the attempt to identify what is, while analytical research attempts to establish how it came to be (Ethridge, 2004). Descriptive research is solving the problem statements that of undertaking audit by organization, cost and benefit of environmental audit, environmental audit role, and accounting treatment for environmental costs, and overall aimed at casting light on current issues if environmental cases or problems through a process of data collection that enables them to describe the accounting treatment in case of cost emerge (Fox \& Bayat, 2007). An important characteristic of descriptive research relates to the fact of environmental devastation, and how worst it, so that can be caused the cost, while descriptive research can employ accounting treatment as well as, the problem emerged. Descriptive studies are closely associated with observational studies, but they are not limited with observation data collection method.

\section{ANALYSIS AND DISCUSSION}

\subsection{ANALYSIS}

4.1.1. Undertaking the Environmental Audit

Some of the reasons why an organization may wish to undertake an environmental audit are pressures from environmental legislation, environmental liabilities and insurance costs, investment and decisions to buy facilities, detailed investigation of specific issues, corporate image and marketing opportunities, concern about the environmental impact of the organization generally, and past environmental accidents Audits enable the management of an organization to see exactly what is happening within the organization and to check the operation of system and procedures. Some environmental auditing programmes have been motivated by the occurrence of an environmental problem or incident, that is, a reactive response, others have been established in response to the desire to anticipate and head off potential problems, that is, the organization takes a proactive stance. The incentives for environmental auditing, and the objectives an organization will have in undertaking such an audit, have diversified since the early days of environmental issues, which is present in society as a whole, and the realization by organizations of the need to integrate these issues into all aspects of their activities. Environmental auditing can help to reveal the likely weaknesses of an organization's strategy, therefore reducing the risk of an unexpected event. A properly prepared and conducted environmental audit will bring real benefits to an organization committed to acting on the results.

4.1.2. The Cost and Benefit of Environmental Audit

There are a number of benefits to a corporate undertaking an environmental audit. Two of the more easily recognized benefits, increased management effectiveness, and cost savings. To manage an organization effectively, 
management must be aware of every aspect of the organization's operational procedures and processes. An environmental audit should reveal any weaknesses in the structures and, when these are rectified, the management can be confident that nothing has been overlooked and nothing unexpected is likely to occur.

An environmental audit can enable management personnel to become aware of many environmental issues of which they formerly may have been less well informed. This is especially the case in organizations with multiple facilities or with large manufacturing operations, where the senior managers and directors are often located at a distance, for example, in the head office. Managers may not have visited many of the sites where there are obvious environmental risks and, even if they have, they may not have the appropriate knowledge or training to identify what risks are present. The use of environmental audits can provide management with the confidence that any actual or potential risks have been identified. However, auditing by itself does not improve environmental performance. An environmental audit merely provides 'snap-shot' of what is happening at that moment in time, and doesn't help to ensure ongoing management effectiveness and the proper operation of systems and procedures. As a tool which aids decision making and management control, an environmental audit is often carried out as part of an overall environmental management system.

An environmental audit should identify opportunities for improvements in an organization's management, and this will often lead to savings in spending. This is particularly common in the case of 'issue' audits, such as the water or waste audit. As an example, waste minimization is an area where there are many opportunities for an organization to save money. Waste requires to be disposed of, and this itself costs money. For instance, companies are charged for disposing of waste into licensed landfill facilities, or it may be necessary to pay for special treatment of a chemical before disposal. Reducing the amount of waste produced can, therefore, lead to savings, as the organization has to dispose of the smaller quantity. An obvious way of minimizing the amount of waste generated is to minimize inputs. Adopting a more efficient process could mean that fewer raw materials are required and that the overall cost of raw materials is therefore reduced. Reductions in the amount of water required can also lead to savings, as organizations are almost always charged for their water usage.

An issue audit will often highlight the need for an ongoing programme of improvements. A waste audit can lead to the implementation of a waste reduction programme, which may feature the major redesign of products or simply minor changes to working practices. Organizations, which carry out an environmental audit in order to establish that they are in compliance with environmental legislation, can benefit financially in another way. An audit identifies any areas where an organization may be in breach of regulations, and if these problems are subsequently corrected, financial loss through plant closures, clean-ups or restrictions imposed by government bodies or through bad publicity can be avoided. The opportunity to make savings is not limited to large companies.

The benefits of environmental auditing described so far are largely financial, and can be measured directly. A range of less tangible benefits can be identified, such as increased awareness of environmental policies and responsibilities among the whole workforce, increased management confidence due to a feeling of security that the compliance (and safety) status of the plant is confirmed and documented, favorable publicity, improved relationship with regulatory authorities, better understanding of consumer demands gain a competitive advantage by minimizing environmental impacts through improved design of products, packages, and processes, and help to ensure the company meets compliance and due diligence requirements. However, there may also be various perceived disadvantages associated with undertaking an environmental audit, for instance, disruption of plant activity while the audit is carried out, the cost of the exercise, and the possible perception by staff in the organization that an audit is a negative process, which assesses their performance. Most of these can be minimized or overcome by careful forward planning to ensure that the audit runs smoothly. Adopting an informal and approachable stance and pointing out the positive aspects of undertaking an audit can dispel any fears or misconceptions held by the staff. The cost of the audit can often be recovered by savings made through improvements identified in the audit and a number of auditing companies' peg their fees to the savings made subsequently or may operate on a no gain, small fee basis.

4.1.3. The role of an environmental audit and management system

One role of an environmental audit is to identify areas for improvement, but an audit does not, in itself, provide the means to implement changes. In order to do this, an environmental audit should be set in the framework of an environmental management system. Environmental audits investigate the current environmental performance of an organization. Audits, therefore, provide information on the activities at that moment in time. Hunt and Johnson (1955), for example, note that environmental auditing on its own cannot provide management with the assurance that environmental practices and performance not only have met but will also continue to meet, legislative requirements and sound corporate policy commitments and expectations. An environmental management system (EMS) provides a mechanism for systematically managing the environmental effects of an organization. EMS provides a framework to identify significant environmental effects, document regulatory requirements, set objectives and targets for future environmental performance, implement procedures and measures for achieving the objectives and targets, and undertake audits to assess environmental performance and the effectiveness of measures to achieve the defined objectives and targets. 
In order to ensure and understand that employees and any other stakeholders comprehend about the management system, environmental management systems usually rely heavily on documentation. Environmental effects, environmental regulations, objectives, and targets, and the procedures are usually all documented. It is important to notice that environmental audit and environmental management systems are not synonymous terms. Seetharaman et.al (2007), presented about environmental accounting as a tool for the environmental management system, revealed that the relationship between the organization and the environment is receiving increasing attention. Currently, a debate on global climate change and biodiversity are becoming more commonplace in the corporate world, together with concern over water, air, and soil pollution. Although the sustainability of economic development is a shared responsibility of the organization, government, and consumers, the organizations can play a vital role in slowing down environmental degradation. It is possible because an organization has financial resources, technological knowledge, and institutional capability and long-term vision to find environmental solutions, An organization can contribute towards sustainable environment by innovating and improving their products and processes in order to use raw materials more efficiently, reduce the waste generated from their processes, improve the waste disposal methods and improve the work conditions. Thus, the programs or activities for keeping pollution under control, zero waste or design for the environments such as product life cycle analysis (LCA), total quality environmental management and others. In this way, the organization can lead to an improvement in overall environmental performance, customers' satisfaction, and company performance.

In EMS, the system is able to improve the environmental performance (Theyel, 2000) in many ways such as stressing on pollution prevention, reduction in cost, compliance with environmental legislation, and improving corporate image. Environmental Management System (EMS): An EMS is an integral part of an overall management system that includes organizational structure, planning, objectives, activities, responsibilities, procedures, processes, and resources for developing, implementing, achieving, reviewing and maintaining environmental policy (definition in ISO14001: 1996). An EMS serves as a systematic approach in managing the environmental aspects of the business. he benefits of EMS are served as self-regulatory compliance to legal and regulatory requirements, to reduce costs from customer audits, better market impression, to increase the efficiency of resources and the ability to adapt changing circumstances.

Environmental Accounting System as environmental management in business has evolved over time, interest has grown in developing a better understanding of environmental-related financial costs and benefits as input to conventional management accounting. The main stimulus is growing evidence that focus on environmental related factors can enhance the profitability and financial position of a business. Environmental accounting is used to assess full environmental costs associated with activities and/or products. Environmental accounting also can be used to track the environmental performance of organizations' in more measurable manner.

In the past, environmental accounting systems were used as a tool to evaluate and disclose environmental impact reduction effects on environmental conservation costs. However, in fact now the EMS in business has evolved, interest has grown in developing a better understanding of environmental related financial costs and benefits as an input to conventional management accounting. For example, the internal costs associated with air emission to the environment are often not identified within conventional management practices. As a result, cost savings relating to environmental pressures frequently remain hidden. These so-called hidden costs are difficult to detect, yet these costs are often chronic in character and can be significant (Pernilla, 2001).

4.1.4. The Environmental Costs on Environmental Accounting

The main component of environmental accounting is the environmental cost. The European Commission Recommendation (2001) makes the distinction between environmental costs and other costs, defining them as costs of the actions undertaken by the economic entity and by third parties in the name of an economic entity with the purpose of preventing, reducing or repairing the environmental damages resulted from operational activities. These costs include waste storage and disposal, soil protection, underground and surface water protection, clean air and climate protection, noise reduction, biodiversity, and landscape protection.

The definition given to environmental costs by the United Nations Conference on Trade and Development (UNCTAD) posits that they "comprise the costs of steps taken, or required to be taken, to manage the environmental impact of an enterprise's activity in an environmentally responsible manner, as well as other costs driven by the environmental objectives and requirements of the enterprise". The Environmental Protection Agency defined environmental costs as being costs with a direct financial impact over entities (internal costs) and individual costs, for which the entity is not responsible (external costs). This definition represents the basis for the distinction between environmental costs, which is seen below (de Beer \& Friend, 2006)

According to the Environmental Protection Agency (1995), internal costs include:

1. Conventional costs, which include costs with equipment, raw materials, and consumables

2. Hidden costs, which refer to the results of assigning environmental costs to indirect costs or overlooking future and contingent costs

3. Contingent costs refer to environmental costs that will not occur with certainty in the future, depending on uncertain future events, such as the costs involved in a future restoration process. 
4. PR costs are less tangible because they cover the subjective perceptions of management, clients, employees, community, and regulators. This category may include costs of the annual environmental reports, as well as costs for environmental activities, such as planting trees.

External costs include the costs of environmental degradation for which the entities are not legally responsible and which have negative consequences on humans, property and their well-being, and can't be always compensated through legal systems. Determining the financial value of external costs is difficult, but, nevertheless, some entities are trying to approach these costs as part of their environmental accounting system. From our point of view, environmental costs are those expenses incurred to prevent, reduce or repair damages caused to the environment, incurred at the initiative of the entity or required by the regulations and rules in place to reduce the environmental impact of the entity and to reduce the environmental risk.

According to Chivu (2015), The application of management policies for environmental costs leads to a reduction in long-term costs and an increase in the benefit claimed. Environmental costs can be reduced or avoided through pollution prevention practices such as redesigning products, input materials substitution, practices and improve the operational level of maintenance. Ileana \& Andrea (2014) environmental cost is a fundamental instrument in providing pertinent information for making correct decisions in the economic entities and in the publication and dissemination of this information in the annual reports and situations of economic entities. The managers of the capital, as well as other parties concerned, to which the economic entity has a certain social responsibility, use accounting to obtain information on the consequences of the economic growth on opportunities and environmental costs. Ileana \& Andrea (2014) also said that environmental costs represent the total expenses borne by an economic entity, voluntarily or as a result of the legal settlements, for the protection and/or reconditioning of the impact that the activity carried out by an economic entity exerts on the environment. An expense is synonymous to a payment representing a cash flow, and the factor deciding that an expense constitutes a cost element is the consumption. The difference between the two indicators consists in the fact that, on a cost level, only material and labor consumptions for a certain period (month, year) are included and the expenses contain the whole financial circuit caused by the environmental actions. Once the increasing problems regarding the environmental protection admitted, the organisms in the field have begun carrying out all kind of actions in this respect so that the Governments were determined to agree on the introduction of mandatory standards for the recondition of damage caused to the environment. Information on the environmental costs is determined in the whole managerial process for substantiating reliable decisions regarding the production cost modeling.

Ileana \& Andrea (2014) consider that on the management accounting level, environmental accounting brings a plus value as follows: new opportunities are discovered, that is innovations on the activities related to the environment, like recycling resources and their use in other activities; it may contribute to the diminution of the environmental cost; it may contribute to the improvement of the price policy; it may contribute to the improvement of the decisional process by the creation of an optimum informational support, namely the separate accentuation of the environmental costs, which leads to an increase of the economic entity profitability, as well; it contributes to the improvement of the quality of the environmental internal/external reporting by means of the environmental costs that are based on the data/information regarding the impact on the environment of different producing activities of an economic entity; it helps increase the competitive advantage of a productive economic entity by means of the environmental management accounting and, respectively, of the specific advertisement, by publicizing, in the media, the efforts of reducing the environmental costs, which constitutes a capital of image favorable to the respective entity; it contributes to personnel attraction and motivation; due to this, social benefits increase, that is the whole population of a country and extrapolated, of the whole planet can win from a healthrelated perspective, by breathing fresher air. All these positive aspects may be included in the entity's annual budget and be distinctly emphasized, in management accounting, by means of distinct/analytical accounts.

\subsection{Discussions}

The objective of the environmental cost accounting is to allow the economic entities, local and governmental collectivities, to have a correct assessment of the impact exerted by the productive activity of an economic entity on the environment. Therefore, the totality of the expenses borne by the productive economic entity - voluntarily or as a result of the legal settlements into force - for the recondition or protection of the environment as a result of the activity carried out are based on the environmental costs. In other words, environmental costs were on the basis of environmental accounting, which, in time have received a different classification, according to certain variables.

Environmental costs and performance are subjected to the management attention for the following considerations, at least: some environmental costs may be reduced considerably or even eliminated by changes on the operational level, by investments in clean technologies, by the re-design of the manufacturing processes and products. Environmental costs (thus, the potential cost economies) may look insignificant, at first sight; by the use of the mechanisms for reducing wastes, in many economic entities the environmental costs and benefits have been brought to light; a better management of the environmental costs may lead to the improvement of the environmental performances and to significant benefits on people's health as well as on the success of the business; 
the correct understanding of the localization of the environmental costs and benefits associated to the production processes and products leads to costs and prices established much more correctly and which may help the entity to design, in the future, more environmentally-friendly processes, products, and services; concurential advantages may result in the demonstration of an environmental orientation of the processes and services.

Environmental costs may be reduced or avoided by pollution prevention practices, such as re-design of products, substitution of material inputs, improvement practices on maintenance operational level, for instance, if for the obtaining of a finished product the use of component $\mathrm{A}$ is necessary, but for the reducing of the impact, the respective component may be substituted by component $\mathrm{B}$, then costs get diminished and thus, considerable cost economies may be obtained. The statistical analysis of the environmental costs is done as a support in the decisional process on a micro and macroeconomic level. The analysis issues regard the macroeconomic level, the consumption of natural - both renewable, and non-renewable - resources, in physical units or, where possible, invaluable units. The environmental cost content is related to the consumption of the factors that caused it and which - for being monitored and emphasized - must have a valuable and quantitative expression.

Therefore, the cost is the value expression of all the factors consumed for the production of environmental services and takes the shape of expenses borne by the environmental service provider. On the basis of the environmental cost, there are existing and materialized labor consumptions, expressed as values - which consumptions take the shape of production and distribution expenses, borne by the providers of environmentallyspecific services. A correct identification and an optimum distribution of the environmental costs per products, works, services or economic processes constitutes the essential factor in the diminution

\section{CONCLUSION}

The necessity of integrating the environment in the financial and decisional system of each economic entity was considered more important. Two forms of accounting which respectively the financial and the managerial, environmental accounting represents the key element for achieving these goals. Environmental cost accounting represents a set of principles and approaches providing essential information for the activities specific to environmental management. Environmental accounting is more than a simple method of calculation representing the environmental costs - it is a system of planning and managing the environmental performance which should reflect the managerial style and commitment of the economic entity management to the environment. As we have presented above, an economic entity may have a different orientation regarding the environmental issues, but we .anticipate that the evolution in time, management style and enterprises' behavior may have a positive impact on the added value of the economic entity in relation to the environment. We must understand that the proactive, planned and quantified commitment may become profitable.

Environmental accounting represents a key element for the assessment, identification, analysis, and recording of the impact produced by the economic activity on the environment and use of such information in the financial and decisional process of the economic entity. Within the present article, we have shown the relevance of the integration of the environmental issues in the financial and decisional system of the economic entity. Environmental accounting can produce a range of benefits for an organization, including cost savings and increased management effectiveness and both large and small organizations can benefit from undertaking an audit. The most important element of environmental accounting is environmental costs. Focus on the environmental costs, environmental costs will be controlled facility. According to the types of environmental costs should be included in the accounting information system. Environmental costs (Environmental activity type costs, costs that represent traditional accounting, Environmental domain type costs, costs which reflect data visibility in the accounting records) have been recorded according to the types of expenses according to their functions should be reflected in costs and expenses of the period.

\section{References}

BangkaPos.com. 2012. 70 persen Kerusakan Lingkungan akibat Sektor Tambang. Jumat, 28 September 2012 http://bangka.tribunnews.com/2012/09/28/70-persen-kerusakan-lingkungan-akibat-tambang.

Bebbington, K.J., R.H.Gray, I.Thomson \& D.Walters.1994.Accountants' Attitudes and Environmentally Sensitive Accounting. Accounting \& Business Research No.94 Spring

Bisnis Indonesia Mobile, 28 May 2012, Inda Marlina. Kerusakan Lingkungan: 5 Raksasa Pertambangan Cemari Sungai http://industri.bisnis.com/read/20120528/44/78719/kerusakan-lingkungan-5-raksasa-pertambangancemari-sungai

Chivu, Ramona Maria.2015.Environmental Costs from the perspective of environmental accounting". Scientific Papers, the journal of business management and applied economics Vol. IV, Issue 3 May 2015

Choudhary R.P.2015.Environmental Audit: A Need for Sustainable Development of Mining Industry. International Journal of Innovative Research in Engineering \& Management. ISSN: 2350-0557, Volume 2, Issue 4, July 2015

De Beer, P., and Friend, F.2006. Environmental accounting: A management tool for enhancing corporate 
environmental and economic performance. Ecological Economics, Vol.58(3), pp. 548-560.

Emeakponuzo, D. E., \& Udih, M.2015. Environmental accounting practices by corporate firms in emerging economies: Empirical evidence from Nigeria. Advances in Research, 3(2), 209-220. doi:10.9734/AIR/2015/12829

Ethridge, D.E. 2004. Research Methodology in Applied Economics. John Wiley \& Sons, p. 24

Eze, Joseph Chukwudi, et.al.2016. The Effects of Environmental Accounting on a Developing Nation :Nigerian Experience. European Journal of Accounting and Finance Research Vol.4, No 1,pp. 17-27, January 2016

Fox, W. \& Bayat, M.S. 2007. A Guide to Managing Research. Juta Publications, p.45

Gray R.H., K.J.Bebbington, D.Walters, and I.Thomson.1995. The greening of enterprise: An exploration of the (non) role environmental accounting and environmental accountants in organizational change. Critical Perspectives on Accounting 6(3) June (pp211-239)

Gray R.H.1992. Accounting and Environmentalism: An exploration of the challenge of gently accounting for accountability, transparency, and sustainability. Accounting Organisations and Society Vol.17 No.5.pp399425.

Gray, R. H.1992. Accounting and Environmentalism: An Exploration of the Challenge of Gently Accounting for Accountability, Transparency, and Sustainability. Accounting, Organizations and Society, 17, 399- 425.

Ileana, Sorina Rakos and Andreea Antohe.2014.Environmental Cost - An Environment Management Accounting Component. International Journal of Academic Research in Accounting, Finance and Management Sciences. Vol. 4 No. 4, October. E-ISSN: 2225-8329.

Jaggi, B. and Zhao, R.1996. Environmental performance and reporting: Perceptions of managers and accounting professionals in Hong Kong, International Journal of Accounting 31(3), 333-346.

Joseph Ufere Kalu, Alias Buang, Godwin Uche Aliagha. 2016. Determinants of voluntary carbon disclosure in the corporate real estate sector of Malaysia. Journal of Environmental Management 182, 519-524.

Magara, N.N. Aming and E. Momanyi.2015.Effect of Environmental Accounting on Company Financial Performance in Kisii Country. British journal of Economics, Management \& Trade 10(1):1-11,2015, Article no. BJEMT. 19909, ISSN: 2278-098X.

MoEF.2016.National Forest Reference Emission Level for Deforestation and Forest Degradation: In the Context of Decision 1/CP.16 para 70 UNFCCC (Encourages developing country Parties to contribute to mitigation actions in the forest sector), Directorate General of Climate Change. The Ministry of Environment and Forestry. Indonesia.

Pernilla,G.2001.Costs of environmental errors (CEE). Greener Management International, Issue 31.

Seetharaman, A, Mohamed Ismail and Saravanan, A S.2007. Environmental Accounting as a tool for the Environmental Management System.JASEM ISSN 1119-8362 Vol 11 (2) 137-145

Senol, Hasan and Hakan Ozcelik.2012. The Importance of Environmental Accounting in the Context of Sustainable Development and Within IFRS Evaluation. Suleyman Demirel University, Isparta, Turkey. International Symposium on Sustainable Development, May 31-June 01 2012, Saravejo.

Tanc, Ahmed and Kadir Gokoglan.2015. The Impact of Environmental Accounting on Strategic Management Accounting: A Research on Manufacturing Companies. International Journal of Economics and Financial Issues. ISSN: 2146-4138

The European Commission Recommendation 2001. The Working Party has been established by Article 29 of Directive 95/46/EC. It is the independent EU Advisory Body on Data The European Commission, Internal Market DG, Functioning and impact of the Internal Market. Co-ordination. Data Internet address: http://europa.eu.int/comm/internal_market/en/media/dataprot/wpdocs/index.htm.

Theyel, Gregory 2000.Management practices for environmental innovation and performance. International Journal of Operations \& Production Management 20(2):249-266 DOI: 10.1108/01443570010304288.

Todea, N, Stancu, I and Udrea.2011.Accounting policies on environmental costs and their calculation method in the entity. Proceedings of the 22nd International DAAAM Symposium, Volume 22, No. 1, ISSN 1726-9679, Vienna, Austria.

Todea, Nicolae et.al.2010.Environmental Accounting- A toll used by the entity for determining environmental costs. Annales Universitatis Apulensis Series Oeconomica, 12 (1),2010.

Unites States Environmental Protection Agency.1995. An Introduction to Environmental Accounting as a Business Management Tool: Key Concepts and Terms, June, EPA, Washington D.C. 